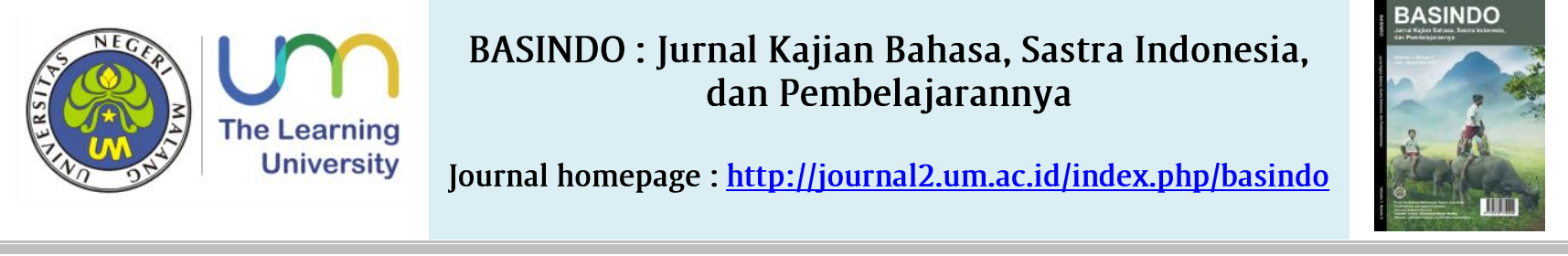

\title{
PEMBENTUKAN KARAKTER MELALUI UNGKAPAN KEPERCAYAAN RAKYAT DALAM MASYARAKAT MINANGKABAU
}

\author{
Dina Ramadhanti* \\ STKIP PGRI Sumatera Barat, mahasiswa Program Doktor Universitas Negeri Malang
}

\section{A R T I K E L}

Kata Kunci:

Karakter

Ungkapan Kepercayaan

Minangkabau

\begin{abstract}
A B S T R A K
Ungkapan kepercayaan rakyat menjadi salah satu bagian dari budaya masyarakat Minangkabau. Ungkapan kepercayaan rakyat merupakan salah satu bentuk sastra lisan yang berkembang dalam masyarakat khususnya masyarakat Kenagarian Salimpat Kecamatan Lembah Gumanti Kabupaten Solok Provinsi Sumatera Barat. Ungkapan kepercayaan rakyat disampaikan secara turun temurun dan mengandung fungsi hiburan dan edukasi. Ungkapan kepercayaan rakyat digunakan sebagai sarana pendidikan karena mengandung nilai-nilai kearifan lokal yang berguna untuk pembentukan karakter. Pilihan kata yang digunakan dalam puisi menggunakan kosakata Minangkabau dan menyiratkan nilai-nilai kearifan lokal. Oleh karena itu, makalah ini ditulis untuk mendeskripsikan pembentukan nilai karakter melalui ungkapan kepercayaan rakyat dalam masyarakat Minangkabau. Metode yang digunakan adalah deskriptif untuk menjelaskan makna dan nilai-nilai karakter yang terdapat dalam ungkapan kepercayaan rakyat sebagai salah satu bentuk sastra lisan. Pilihan kata yang sarat dengan alam Minangkabau menjadi ciri khas ungkapan kepercayaan rakyat Minangkabau. Masyarakat dahulunya bahkan memberikan petuah dan nasihat kepada anaknya melalui ungkapan kepercayaan rakyat. Saat ini ungkapan kepercayaan rakyat yang menggunakan bahasa Minangkabau tidak lagi dikenal oleh generasi muda, bahkan beberapa kosakata yang digunakan tidak lagi dikenal. Oleh karena itu, perlu adanya pemertahanan keberadaan ungkapan kepercayaan rakyat ini sebagai bagian dari budaya masyakat Minangkabau dan sebagai upaya pembentukan karakter para generasi penerus.
\end{abstract}

(C) 2017 BASINDO Journal. All rights reserved

\section{PENDAHULUAN}

Minangkabau dikenal sebagai suku bangsa yang mempunyai ciri khas tertentu. Minangkabau mempunyai berbagai bentuk tradisi yang disajikan secara lisan dari generasi ke generasi. Generasi penerus dapat mengetahui berbagai bentuk tradisi ini karena terus disampaikan dan dijadikan pegangan dalam menyikapi hidup. Apalagi Minangkabau terkenal dengan falsafahnya Alam Takambang Jadi Guru. Segala hal yang terjadi di alam dijadikan sebagai pedoman dalam kehidupan. Begitupula dalam tradisi masyarakat Minangkabau semua berasal dari alam sekitar. Misalnya dalam mengajarkan nilai-nilai kehidupan selalu menggunakan alam sebagai sumber penciptaan. Hal inilah yang menjadikan Minangkabau khas dengan kearifan lokalnya yang menjadikan alam sebagai sumber kehidupan.

Alam dijadikan sebagai sumber penciptaan karya yang terus membudaya dalam kalangan masyarakat Minangkabau. Semua hasil karya itu awalnya disajikan dalam bentuk lisan dan disampaikan dari mulut ke telinga secara turun temurun dari generasi ke generasi. Hal ini juga disampaikan oleh Soetarno (2008:6) bahwa sastra lisan adalah kesastraan yang hanya dituturkan dari mulut ke mulut dan disebarkan secara lisan. Sastra lisan menjadi bagian dari tradisi masyarakat yang menggunakan bahasa sebagai medium utamanya. Dalam kehidupan sehari-hari sastra lisan dituturkan oleh ibu kepada anaknya, seorang tukang cerita kepada para pendengarnya, guru kepada muridnya, ataupun antar sesama anggota masyarakat. Hal ini memperlihatkan bahwa sastra lisan sangat dekat dengan kehidupan masyarakat karena mengandung gagasan, pikiran, ajaran, dan harapan masyarakat. Suasana kebersamaan yang dihasilkan dari sastra lisan berdampak pada menguatnya ikatan batin di antara anggota masyarakat.

\footnotetext{
${ }^{*}$ Corresponding author.

E-mail addresses: dina@stkip-pgri-sumbar.ac.id, dina_ramadhanti89@yahoo.com (Dina Ramadhanti)
} 
Ungkapan kepercayaan rakyat merupakan bagian dari sastra sebagian lisan. Dikatakan sebagian lisan karena dalam ungkapan rakyat terkandung unsur lisan dan unsur bukan lisan. Unsur lisan berupa ungkapannya, sedangkan unsur bukan lisan adalah sesuatu yang gaib yang terkandung dalam ungkapan itu. Ungkapan ini mengandung sesuatu yang magis sehingga mau tidak mau masyarakat harus mengikuti hal yang dituturkan sebagai aturan hidup. Menurut Danandjaya (1991), fungsi utama ungkapan kepercayaan rakyat bagi masyarakat adalah untuk menyampaikan isi hati, perasaan, keinginan si penutur dengan bahasa kiasan yang bersifat tidak kasar, tidak menyinggung, tetap saling menyegani, dan menghormati.

Ungkapan kepercayaan rakyat atau oleh masyarakat modern dikatakan takhyul karena tidak masuk akal dan tidak sesuai dengan perkembangan zaman. Pengaruh globalisasi dan ilmu pengetahuan menjadikan kepercayaan rakyat/takhyul ini kurang dipercayai oleh anak-anak muda karena mereka telah melihat semua fenomena yang terjadi dan dihubungkan dengan ilmu pengetahuan yang mereka miliki. Akan tetapi, sebagian masyarakat masih menggunakan ungkapan kepercayaan/takhyul ini untuk mendidik anak-anaknya agar selalu memegang norma-norma sebagai kaidah yang mengatur kehidupan.

Keyakinan terhadap nilai kebenaran yang terkandung dalam ungkapan kepercayaan rakyat ini, sudah melekat pada jiwa setiap generasi bahkan sejak para nenek moyang masih menganut ajaran animisme dan dinamisme. Nilai budaya yang terkandung dalam kepercayaan rakyat ini adalah adanya keyakinan masyarakat terhadap sesuatu yang sifatnya mistik atau gaib. Kepercayaan ini hingga sekarang masih dianggap benar oleh sebagian orang yang mempercayainya (Fitrahayunitisna dan Zulvarina, 2017). Takhyul dapat menjadi sebuah peringatan atau tanda agar dapat mawas diri bagi orang-orang yang meyakini hal tersebut. Akan tetapi, karena adanya hal-hal yang dianggap tabu tersebut, maka sebagian orang atau keseluruhan orang juga merasa takut untuk melanggar hal yang dianggapnya mistis.

Ungkapan kepercayaan rakyat /takhyul dapat dijadikan sebagai upaya pembentukan karakter para generasi. Karakter yang pada dasarnya sudah ada ketika lahir akan semakin terbentuk dengan baik dengan adanya rangsanganrangsangan yang baik dari lingkungan sekitar. Salah satunya dengan adanya ungkapan kepercayaan rakyat sebagai salah satu bentuk aturan atau kepercayaan dalam kehidupan sehari-hari. Ungkapan kepercayaan rakyat dapat dijadikan stimulus dalam membentuk karakter yang lebih baik. Stephen Covey, seorang ahli psikologi mengatakan bahwa pembentukan karakter didasari oleh hukum aksi dan reaksi atau hukum stimulus dan respons, atau disebut sebagai hukum rangsangan dan respon. Stimulus dan responlah membentuk jati diri seseorang. Ungkapan kepercayaan rakyat sebagai bentuk stimulus dalam pembentukan karakter akan menjadikan generasi tumbuh menjadi pribadi yang berkarakter, paham akan norma dan budaya yang berlaku dalam masyarakat, dan tidak mudah terpengaruh oleh arus globalisasi.

Menurut Megawangi (2003:7) kualitas karakter meliputi sembilan pilar. Kesembilan pilar kualitas karakter tersebut, yaitu: (1) cinta Tuhan dan segenap ciptaan-Nya; (2) tanggung jawaab, disiplin dan mandiri; (3) jujur/amanah dan arif; (4) hormat dan santun; (5) dermawan, suka menolong dan gotong royong; (6) percaya diri, kreatif, dan pekerja keras; (7) kepemimpinan dan adil; (8) baik dan rendah hati; (9) toleran, cinta damai dan kesantunan. Seseorang dikatakan memiliki karakter yang baik apabila kesembilan kualitas karakter tersebut ada pada dirinya.

Kualitas karakter baik yang harus dimiliki seseorang tidak serta merta langsung dimilikinya. Karakter baik yang dimiliki seseorang sangat dipengaruhi oleh karakter bawaan dan pengaruh lingkungannya. Pada dasarnya semua manusia itu pada mulanya memiliki karakter yang baik Dalam bahasa agama Islam, semua manusia itu pada awalnya dilahirkan fitrah, putih bersih tidak bernoda atau berdosa. Perkembangan dirinyalah yang boleh jadi diakibatkan salah pergaulan yang dapat membuat dirinya berdosa (Yulianto, n.d.)

Berdasarkan hal-hal di atas, maka permasalahan yang akan dibahas dalam makalah ini adalah bagaimanakah pembentukan nilai karakter yang terkandung dalam ungkapan kepercayaan rakyat? Dengan demikian, maka makalah ini bertujuan untuk menjelaskan pembentukan karakter melalui ungkapan kepercayaan rakyat dalam masyarakat Minangkabau khususnya di Kanagarian Salimpat Kecamatan Lembah Gumanti Kabupaten Solok Provinsi Sumatera Barat.

\section{METODE PENELITIAN}

Jenis penelitian ini adalah penelitian kualitatif. Bogdan \& Biklen (1998) menyatakan bahwa penelitian kualitatif adalah penelitian yang bermaksud untuk memahami fenomena tentang apa yang dialami subjek penelitian berupa persepsi, motivasi, tindakan, dan sebagainya. Pendekatan kualitatif digunakan atas dasar permasalahan yang dikaji, yaitu mendeskripsikan pembentukan karakter melalui ungkapan kepercayaan rakyat dalam masyarakat Minangkabau khususnya di Kanagarian Salimpat Kecamatan Lembah Gumanti Kabupaten Solok Provinsi Sumatera Barat. Informasi-informasi yang berkaitan dengan ungkapan kepercayaan rakyat dalam masyarakat Minangkabau didapatkan berdasarkan fakta-fakta yang ditemukan di lapangan, nyata, dan tanpa adanya pengaruh luar. Metode yang digunakan adalah metode deskriptif. Menurut Ratna (2013:53), metode deskriptif adalah metode yang digunakan untuk mendeskripsikan fakta-fakta yang kemudian disusul dengan analisis.

Data penelitian ini adalah kata-kata atau informasi yang terkait dengan ungkapan kepercayaan rakyat yang diperoleh melalui informan berdasarkan teknik purposive sampling. Instrumen yang digunakan adalah alat perekam, lembar pencatatan, dan pedoman wawancara. Data penelitian dianalisis melalui empat tahap, yaitu identifikasi, klasifikasi, interpretasi, dan pelaporan. Pengabsahan data dilakukan dengan teknik triangulasi. 


\section{HASIL PENELITIAN DAN PEMBAHASAN}

Penelitian ini dilakukan untuk mendeskripsikan nilai-nilai yang terkandung dalam ungkapan kepercayaan rakyat sebagai upaya pembentukan karakter. Nilai-nilai karakter yang dilihat sesuai dengan pendapat Muchson (2013:80), yaitu karakter yang merupakan pengejawantahan nilai-nilai perilaku manusia yang berhubungan Tuhan Yang Maha Esa, diri sendiri, sesama manusia, lingkungan dan kebangsaan.

\section{Pembentukan karakter melalui ungkapan kepercayaan rakyat yang}

berhubungan dengan Tuhan Yang Maha Esa

Ungkapan kepercayaan rakyat yang berhubungan dengan Tuhan Yang Maha Esa adalah keinginan yang kuat untuk menjaga dan mencintai segenap ciptaan Tuhan Yang Maha Esa. Karakter yang dituntut adalah menghargai ciptaan Tuhan dengan tidak menyakiti ciptaan Tuhan, seperti tampak pada ungkapan kepercayaan rakyat berikut ini.

Ibu hamil idak bulieh mambunuah ula, bako anak e basisiek sarupo ula.

(Ibu hamil tidak boleh membunuh ular, nanti dikhawatirkan anaknya yang lahir memiliki sisik seperti ular )

Ungkapan kepercayaan rakyat ini tergolong takhyul di sekitar lingkungan hidup manusia. Ungkapan ini dalam masyarakat Minangkabau masih dipercayai hingga kini. Ular adalah makhluk ciptaan Tuhan Yang Maha Esa yang juga mempunyai hak untuk hidup. Ibu yang sedang mengandung/hamil harus menjaga tingkah lakunya selama proses kehamilan agar anak yang dikandung tumbuh dengan baik dan jauh dari perilaku yang tidak baik.

Ungkapan kepercayaan rakyat juga mengajarkan untuk seorang ibu dapat menjaga bayi yang baru dilahirkan sebagai bentuk ciptaan Tuhan Yang Maha Esa, misalnya dengan menjaga kebersihan pakaian bayi, seperti tercermin dalam ungkapan kepercayaan rakyat berikut ini.

Jan manjamua baduang anak di muko rumah bako kanai palasik.

(Jangan menjemur popok/pakaian bayi di depan rumah nanti kena palasik).

Ungkapan kepercayaan ini dalam masyarakat Minangkabau mengajarkan supaya seorang ibu dapat berhati-hati dalam menjaga bayinya. Menjemur pakaian bayi di sembarangan tempat dapat merusak pemandangan apalagi aroma bayi sangat khas. Kepercayaan ilmu hitam bagi masyarakat tertentu akan memudahkan mereka meniupkan roh jahat melalui pakaian bayi itu. Hingga kini ungkapan ini masih menjadi aturan hidup orang Minangkabau karena rasa khawatirnya terhadap kesehatan bayinya. Hal lain sebenarnya yang tersirat dari ungkapan ini adalah jika seandainya pakaian bayi dijemur sembarangan tentu akan dihinggapi ulat dan tentu saja hal ini akan mengganggu kenyamanan si bayi.

Ungkapan kepercayaan rakyat mengajarkan masyarakat untuk senantiasa mengingat Tuhan dan melaksanakan ibadah tepat waktu dan tidak melakukan kegiatan lain di waktu sholat. Misalnya tidak berjalan-jalan ketika waktu maghrib datang, seperti dalam ungkapan berikut ini.

Anak gadih, anak bujang, tuo, mudo, idak bulieh bajalan di ari sanjo, bako sakik, setan banyak bakaliaran.

(anak gadis, anak laki-laki, tua, muda, tidak boleh berjalan diwaktu senja, nanti bisa sakit, setan banyak yang

berkeliaran)

Ungkapan kepercayaan ini bagi masyarakat Minangkabau menyiratkan agar anak gadis, anak laki-laki, tua, muda tidak diperbolehkan berjalan di waktu senja karena sudah waktunya sholat maghrib. Orang-orang harus mempersiapkan diri untuk beribadah. Kegiatan lain yang dilakukan hanya akan mengganggu kenyamanan orang lain untuk beribadah. Ungkapan kepercayaan rakyat lainnya yang sejalan dengan aturan beribadah ini terlihat pada ungkapan berikut ini.

Kok sadang magarik idak bulieh main pisau, bako talaluan.

(Kalau sadang maghrib tidak boleh main pisau, nanti luka)

Ketika waktu maghrib telah masuk, dilarang melakukan pekerjaan lain selain mempersiapkan diri untuk beribadah. Hal ini dilakukan sebagai bentuk kewajiban sebagai makhluk ciptaan Tuhan.

Sebagai makhluk ciptaan Tuhan Yang Maha Esa, masyarakat juga dituntut untuk menghargai tanaman sebagai bentuk ciptaan Tuhan. Ketika proses bertani berlangsung harus dikerjakan dengan sungguh sebagai bentuk syukur kepada sang pencipta. Misalnya terdapat pada ungkapan berikut ini.

Kok mananam jaguang idak bulieh galak, bako jarang isi e.

(Kalau menanam jagung, tidak boleh sambil tertawa, nanti buah/isinya jarang)

Ungkapan ini mengajarkan agar teliti dan tidak boleh melakukan hal-hal lain ketika melakukan pekerjaan. Ungkapan ini juga menyiratkan agar dapat memilih bibit yang baik untuk pertanian. Apapun yang ditanam asalkan menggunakan bibit yang unggul dan perawatan yang baik akan membuahkan hasil yang baik pula. Menjaga tanaman agar tumbuh dengan baik merupakan bentuk ungkapan syukur kepada Tuhan Yang Maha Esa.

Masyarakat Minangkabau juga harus menerima takdir dari Tuhan Yang Maha Esa termasuk kematian. Sehubungan dengan itu, ada aturan yang mesti diikuti untuk dapat menerima setiap kelahiran dan kematian yang digariskan oleh Tuhan Yang Maha Esa, seperti pada ungkapan berikut ini.

Kok pai bajalan basobok jo urang nan dulu, idak bulieh manaruih an pai, bako udi di jalan.

(Kalau pergi berjalan bertemu dengan orang yang meninggal, tidak boleh meneruskan perjalanan, nanti sial di jalan).

Masyarakat Minangkabau dituntut untuk dapat menghormati orang yang telah meninggal dan peringatan agar senantiasa mengingat kematian. Apabila bertemu dengan saudara atau tetangga yang meninggal agar dapat 
meninggalkan rutinitas yang dilakukan. Setelah proses pemakaman selesai diperbolehkan melakukan pekerjaan lain. Bagi masyarakat Minangkabau, apabila dalam perjalanan bertemu dengan sekelompok orang yang akan menuju ke pemakaman, maka kendaraannya harus berhenti dan melanjutkan perjalanan setelah sekelompok orang itu pergi. Hal ini dilakukan sebagai bentuk toleran dan penghormatan terhadap orang yang telah meninggal.

Aturan lain yang berhubungan dengan bentuk penghormatan terhadap orang yang telah meninggal juga tampak pada ungkapan berikut ini.

Urang maningga idak bulieh kanai aie mato, bako sakik dek e.

(Orang yang meninggal tidak boleh terkena air mata, nanti orang yang meninggal itu kesakitan).

Ungkapan ini menyiratkan agar tidak berlebihan menangisi orang yang sudah meninggal karena semua itu sudah menjadi kehendak Tuhan Yang Maha Esa. Ungkapan ini muncul karena orang Minangkabau meyakini bahwa sampai 100 hari, arwah orang yang sudah meninggal masih ada di dunia, setelah pelepasan 100 hari arwah tersebut akan benar-benar pergi meninggalkan dunia. Jika orang yang masih hidup meratapi kepergian orang yang sudah meninggal maka arwah yang sudah meninggal tidak akan tenang. Hal lain dari ungkapan ini adalah untuk menghibur orang yang ditinggalkan supaya sabar menerima cobaan dari Tuhan Yang Maha Esa.

\section{Pembentukan karakter melalui ungkapan kepercayaan rakyat yang} berhubungan dengan diri sendiri

Ungkapan kepercayaan rakyat yang berhubungan dengan diri sendiri dalam upaya pembentukan karakter adalah agar dapat menghargai diri sendiri, menjunjung tinggi sopan santun, bersikap wajar dan tidak berlebihan. Hal ini berlaku bagi semua masyarakat Minangkabau. Seperti ungkapan untuk anak laki-laki Minangkabau berikut ini.

Anak bujang idak bulieh makan kapalo nasi bako dak bisa punyo anak.

(anak laki-laki tidak boleh memakan kepala nasi/bagian atas nasi yang baru dimasak nanti tidak bisa memperoleh keturunan).

Ungkapan ini mengajarkan bahwa untuk selalu menghargai saudara laki-laki dalam keluarga di Minangkabau. Orang Minangkabau mengganggap bahwa kepala nasi itu tidak baik dimakan oleh anak laki-laki karena masih lembek dan masih mengandung uap air. Ungkapan ini muncul karena menurut ilmu kesehatan kepala nasi mengandung butir-butir nasi yang tidak baik bagi perkembangan anak laki-laki sehingga diyakini sulit memperoleh keturunan. Ungkapan ini masih dipercayai bagi sebagian masyarakat dan tidak diperbolehkan laki-laki di Rumah Gadang memakan kepala nasi. Hal ini sebenarnya menyiratkan agar menghargai saudara laki-laki dan selalu memberikan sesuatu yang baik kepadanya termasuk makanan. Ungkapan ini bersifat konvensi yang mengajarkan agar memperlakukan anak laki-laki secara baik karena bagi masyarakat setempat laki-laki sangat dihargai sebagai mamak di rumahnya dan urang sumando di rumah istrinya.

Ungkapan kepercayaan lain bagi perempuan Minang yang berhubungan dengan diri sendiri tampak pada ungkapan berikut ini.

Idak bulieh mangarek kuku malam ari, bako pamburuak dagiang.

(Tidak boleh memotong kuku malam hari, nanti jelek kulit/kulitnya belang).

Ungkapan ini mengajarkan agar gadis Minang dapat melakukan sesuatu itu sesuai waktunya. Memotong kuku malam hari bisa menyebabkan luka karena pencahayaan yang kurang bagus. Ungkapan ini tidak terlalu dipercayai lagi oleh masyarakat karena masih ada yang memotong kuku di malam hari. Hal ini tentu harus menjadi perhatian agar dapat melakukan sesuatu sesuai waktunya dan tidak sembarang tempat. Ungkapan lain yang berhubungan dengan kesehatan diri sendiri terdapat pada ungkapan berikut ini.

Pakih nan tumbuah madok ka batang aie idak bulieh di buek samba, bako paniang awak dek e.

(Pakis yang tumbuh menghadap ke sungai tidak boleh dibuat makanan, nanti sakit kepala).

Ungkapan ini mengajarkan agar selektif dalam memilih bahan yang akan dimasak karena akan berpengaruh pada kesehatan tubuh kita. Sebelum memasak makanan harus dilihat apakah bahan yang digunakan sudah memperhatikan syarat kebersihan atau belum. Ungkapan ini muncul karena tanaman yang tumbuh di sembarang tempat tidak semuanya bisa dikonsumsi oleh masyarakat.

Ungkapan lain yang berhubungan dengan sopan santun seorang perempuan Minang juga tampak pada ungkapan berikut ini.

Anak gadih dak bulieh makan jo saok panci, tatutuik pangana.

(Anak gadis tidak boleh makan dengan tutup panci, nanti susah berpikir).

Ungkapan ini mengajarkan supaya perempuan Minang tumbuh menjadi pribadi yang menghargai dirinya sendiri dengan menjaga sopan santun, termasuk ketika makan. Makan dengan menggunakan tutup panci dianggap tidak sopan, sebaiknya makan dengan piring. Ungkapan ini menyiratkan agar anak perempuan menjaga norma kesopanan, karena makan di panci tidak bagus di lihat orang. Tata cara makan yang menjadi aturan seorang perempuan Minang tampak pada ungkapan berikut ini.

Kok makan dak bulieh sampai kariang pinggan, bako bansek iduik.

(Kalau makan tidak boleh kering/harus disiram, nanti serba kekurangan hidup). 
Masyarakat Minangkabau dalam hidup diajarkan untuk mengingat saat susah dan tidak berlebihan saat ada. Untuk aturan makan saja diajarkan agar menyiram piring setelah makan, selain memudahkan mencuci juga mengajarkan etika. Makan sewajarnya menunjukkan bahwa orang Minang bukanlah orang yang rakus atau tamak. Aturan untuk tidak berlebih-lebihan tampak pada ungkapan berikut ini.

Idak bulieh galak gadang-gadang, bako manangih dek e lai.

(Tidak boleh tertawa lebar-lebar, nanti menangis).

Perempuan Minang harus dapat hidup dengan memperhatikan tata karma, baik dalam bersikap dan bertingkah laku. Segala gerak-gerik perempuan Minang harus sesuai dengan norma kesopanan untuk menjaga martabat dan harga diri. Tertawa lebar-lebar itu tidak baik dan dianggap menyalahi norma. Ungkapan ini bertujuan agar perempuan Minang senantiasa menjaga kesopanan, tidak boleh bersikap berlebihan, apalagi yang menyalahi norma-norma kesopanan. berikut ini.

Ungkapan lain yang berhubungan dengan aturan untuk perempuan Minangkabau terlihat pada tuturan

Idak bulieh datang ka tampek nan langang tangah hari bako tasapo.

(dilarang mendatangi tempat yang sunyi di tengah hari nanti tertegur roh halus).

Ungkapan ini menyiratkan bahwa perempuan Minang tidak boleh bepergian ke suatu tempat yang sunyi di tengah hari, karena adanya anggapan akan disapa oleh roh nenek moyang dan bisa menyebabkan sakit. Ungkapan ini bertujuan agar perempuan Minang selalu memperhatikan tempat yang akan didatangi, jelas untuk tujuan apa mendatangi tempat itu dan diketahui oleh keluarga terdekat. Selain itu juga ada ungkapan berikut ini.

Idak bulieh mandi di tangah hari pakak, bako tasapo.

(Tidak boleh mandi di siang hari yang terik, nanti ditegur oleh makhluk halus).

Ungkapan ini menyiratkan bahwa perempuan Minang harus melakukan sesuatu sesuai waktunya tidak boleh sembarangan. Tidak boleh mandi jika matahari sedang terik, karena menyebabkan sakit kepala. Ungkapan ini mengajarkan agar tidak mandi jika matahari sedang terik. Mandi di saat matahari sedang tinggi atau terik mengakibatkan sakit.

\section{Pembentukan karakter melalui ungkapan kepercayaan rakyat yang berhubungan dengan sesama manusia}

Ungkapan kepercayaan rakyat yang berhubungan dengan hubungan sesama manusia sebagai upaya pembentukan karakter tampak dari sikap hidup sehari-hari. Ada sejumlah aturan norma yang mesti diikuti dalam pergaulan hidup sehari-hari, seperti saling menghargai, saling menghormati, toleransi, tolong menolong, gotong royong, dermawan, dan sebagainya. Misalnya terlihat pada ungkapan berikut ini.

Idak bulieh mangikih batu lado jo sendok basi, bako sakik rajo singo anak laki-laki awak.

(Tidak boleh mengikis batu ulakan cabe dengan sendok yang terbuat dari besi atau stanlesstil, nanti anak laki-

laki kita terkena penyakit raja singa).

Penyakit raja singa merupakan penyakit yang sangat berbahaya. Masyarakat berusaha menghindari hal-hal yang dapat menyebabkan penyakit itu. Agar tidak terkena penyakit berbahaya seperti itu, muncul ungkapan tersebut agar masyarakat berhati-hati dalam berbuat. Akan tetapi, ungkapan tersebut menyiratkan agar melakukan sesuatu sesuai dengan aturan. Mengambil cabe dari ulakan cabe yang terbuat dari batu menggunakan sendok dari besi menimbulkan suara-suara yang dapat mengganggu kenyamanan orang lain dan itu dipandang tidak sopan. Agar masyarakat tidak melakukan hal itu, maka ditakut-takuti dengan munculnya penyakit berbahaya seperti raja singa. Apalagi raja singa merupakan penyakit yang mesti dihindari oleh anak laki-laki yang menghuni rumah tersebut. Hal ini masih dipercayai oleh sebagian masyarakat karena rasa sayangnya terhadap anak laki-laki mereka.

Ungkapan lain yang berhubungan dengan perilaku terhadap sesama tampak pada ungkapan berikut ini.

Idak bulieh manggareteh sambarangan, bako nan dak utang nan tabayie.

(Tidak boleh manggareteh atau memukul-mukul dinding/lantai dengan jari tengah nanti membayar hutang).

Dalam masyarakat Minangkabau segala aturan hidup menjadi rambu-rambu dalam kehidupan sehari-hari. Misalnya di Rumah Gadang aturan makan, aturan berbicara, dan aturan duduk diatur demi menghormati mamak rumah dan bundo kanduang. Ketika duduk dilarang melakukan perbuatan yang mengganggu kenyamanan seperti memukul-mukul dengan jari karena dianggap tidak sopan. Ungkapan ini bertujuan agar selalu memperhatikan norma kesopanan, bunyibunyi yang ditimbulkan akan mengganggu kenyamanan orang lain.

Selain aturan duduk, aturan bergaul dengan lawan jenis pun diatur demi menjaga kenyamanan hidup bersama, seperti pada ungkapan berikut ini.

Idak bulieh mancacek anak gadih/anak bujang urang beko manuruik.

(tidak boleh menghina/mencaci anak gadis/anak laki-laki orang nanti berubah jadi suka).

Tata aturan pergaulan antara laki-laki dan perempuan sangat dijaga. Tidak boleh menghina orang lain karena orang yang menghina belum tentu lebih baik dari yang dihina dan boleh jadi akan menyukai orang tersebut jika terlalu menyakiti hati orang lain. Ungkapan ini muncul karena dahulunya orang gampang memberikan ilmu hitam atau pakasiah kepada orang yang telah menghinanya. Sampai kini ini menjadi aturan yang masih ditaati untuk menjaga 
kesopanan berbicara perempuan terhadap laki-laki. Dengan kata lain, ungkapan ini bertujuan agar perempuan Minang senantiasa menjaga setiap ucapan dan tidak menyinggung perasaan orang lain. Ungkapan lain yang sejenis dengan ini tampak pada tuturan berikut ini.

Anak gadih idak bulieh mampacaruik-an laki-laki nan dak disuko, bako dak dapek jodoh.

(Anak gadis tidak boleh berkata kotor kepada laki-laki yang tidak disukainya, nanti tidak dapat jodoh).

Ungkapan ini juga mengajarkan agar perempuan Minang senantiasa menjaga ucapan dan tingkah lakunya. Perempuan minang harus tumbuh menjadi pribadi yang menjaga martabat dan harga diri, salah satunya dengan menjaga ucapan. Ucapan yang baik saja yang boleh diungkapkan. Itulah ciri khas perempuan Minang.

Selain aturan bersikap dan bertingkah laku, juga terdapat aturan tidur di Rumah Gadang agar sesuai dengan norma, seperti tampak pada ungkapan berikut ini.

Idak bulieh lalok di tangah-tangah rumah bako dilangkahi setan.

(tidak boleh tidur di ruang tengah rumah nanti dilangkahi setan).

Kamar tidur di Rumah Gadang juag diatur sedemikian rupa demi kenyamanan penghuni rumah. Agar aturan itu tetap terlaksana maka muncul ungkapan ini untuk mengajarkan agar tidur di tempat yang seharusnya. Tidur sebaiknya di kamar, jangan di ruang tengah karena ruangan itu digunakan untuk berkumpul anggota keluarga. Selain itu, tidur di tengah-tengah ruangan akan mengganggu kenyamanan orang yang ada di dalam rumah.

\section{Pembentukan karakter melalui ungkapan kepercayaan rakyat yang} berhubungan lingkungan dan kebangsaan

Ungkapan kepercayaan rakyat yang berhubungan dengan lingkungan dan kebangsaan dalam upaya pembentukan karakter tampak dari aturan-aturan yang harus dipatuhi ketika berhadapan dengan alam, seperti tampak pada ungkapan berikut ini.

Idak bulieh mamijak pasupadan tanah awak, bako rabun mato.

(Tidak boleh menginjak batas tanah kita, nanti mata buta).

Ungkapan ini menjadi aturan yang masih dipercayai oleh masyarakat Minang agar dapat berperilaku sesuai dengan aturan dan tidak seenaknya saja. Apapun yang dilakukan dan kemanapun pergi harus berhati-hati dan selalu berupaya menghindari hal-hal yang tidak diinginkan. Ungkapan ini bertujuan agar kita mengetahui mana yang milik kita dan mana yang milik orang lain. Jangan sampai kita mengambil hak orang lain. Ungkapan ini sebagian besar masih dipercayai oleh sebagian besar mayarakat agar dapat menghargai diri sendiri dan orang lain. Ungkapan lain yang sejenis dengan ini tampak pada tuturan berikut ini.

Idak bulieh managak-an paga di ateh tunggue lapuak, bako sakik garaman.

(Tidak boleh membuat pagar di atas tunggul pohon yang lapuk, nanti sakit gigi).

Untuk mendirikan Rumah Gadang ada sejumlah aturan dan syarat yang harus dipenuhi oleh masyarakat. Bahkan pembangunan Rumah Gadang dilakukan secara adat dan dilakukan secara bersama-sama. Sebelum mendirikan pagar, harusnya bersihkan dulu tempatnya agar terhindar dari hal-hal yang tidak diinginkan dan untuk menjaga kebersihan dan kerapian. Ungkapan kepercayaan ini muncul dengan tujuan agar masyarakat dalam mendirikan bangunan memperhatikan situasi dan kondisi. Hal ini untuk menjaga agar bangunan tersebut bisa bertahan lama.

Ungkapan kepercayaan rakyat lainnya yang berhubungan dengan aturan mendirikan bangunan tampak pada tuturan berikut ini.

Idak bulieh mambuek rumah di ateh tunggue, bako pakak pauni rumah.

(Tidak boleh mendirikan rumah/bangunan di atas tunggul pohon, nanti penghuni rumah tidak bisa mendengar/tuli).

Ungkapan ini menyiratkan agar mencari tempat yang layak untuk mendirikan rumah dan tidak boleh sembarangan tempat. Mendirikan bangunan yang tidak sesuai dengan aturan akan berakibat pada penghuni rumah. Ungkapan ini masih dipercayai masyarakat dalam tata aturan mendirikan bangunan rumah, seperti tidak boleh membelakangi matahari, dan sebagainya. Ungkapan lain yang sejenis tampak pada tuturan berikut ini.

Idak bulieh mambuek rumah dijajak rumah tabaka, bako tabaka rumah baliek.

(Tidak boleh membangun perumahan di tanah bekas rumah terbakar, nanti rumah yang dibangun terbakar kembali).

Ungkapan ini menyiratkan bahwa untuk mendirikan sebuah bangunan harus diperhatikan tempat dan kondisinya. Rumah untuk tempat tinggal harus dibangun di atas tanah yang jelas dan sesuai dengan kebutuhan.

\section{PENUTUP}

Ungkapan kepercayaan rakyat dapat dijadikan sebagai rambu-rambu atau pedoman dalam menyikapi hidup. Jika masyarakat Minang hidup dengan mematuhi aturan-aturan dan norma yang berlaku, maka ia akan terbiasa menjadi orang yang baik dan dengan sendirinya akan berkembanglah karakter yang baik. Seperti yang telah dijelaskan, bahwa karakter seseorang bersifat bawaan dan akan tumbuh dengan baik sesuai dengan stimulus yang diberikan. Ini seperti hubungan stimulus dan respon. Jika stimulus yang diberikan baik, maka respon yang muncul pun akan baik. 
Ungkapan kepercayaan rakyat dalam hal ini dijadikan sebagai stimulus yang diharapkan akan memunculkan respon berupa karakter yang baik. Stimulus yang diberikan berupa tuturan yang sifatnya melarang dengan kata-kata penuh nasehat dan mengandung ajaran hidup. Respon yang diharapkan berupa perubahan bentuk tingkah laku yang yang tidak baik menjadi baik, yang baik menjadi lebih baik. Dengan adanya ungkapan kepercayaan rakyat sebagai stimulus akan terbentuklah respon berupa karakter yang baik, karakter yang baik sebagai makhluk ciptaan Tuhan Yang Maha Esa, karakter yang baik terhadap diri sendiri, sesama manusia, dan lingkungan sehari-hari.

\section{DAFTAR RUJUKAN}

Bogdan, Robert C. dan Biklen, Knopp S. 1998. Qualitative Research in Education: An Introduction to Theory and Methods. Boston: Allyn and Bacon, Inc.

Danandjaja, James. 1991. Folklor Indonesia: Ilmu Gosip, Dongeng, dan Lain-lain cetakan III. Jakarta: Pustaka Utama Grafiti.

Fitrahayunitisna dan Zulvarina, P. (2017). The Efforts to Strengthen National Identity Through Ethical Value and Local Wisdom in Oral Literature. ISLLAC : Journal of Intensive Studies on Language, Literature, Art, and Culture,

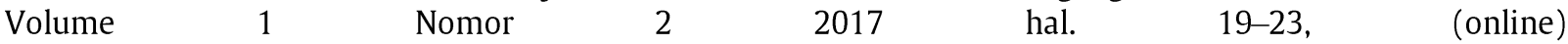
http://journal2.um.ac.id/index.php/jisllac/article/view/1918/1119, diakses 19 Desember 2017

Megawangi, Ratna.2003. Pembentukan Karakter untuk Membangun Masyarakat Madani. Indonesia Heritage Foundation.

Muchson, Ali. 2013. Sastra Sebagai Media Pembentukan Karakter (dalam prosiding Sastra dan Pembangunan Karakter Manusia). Manado: Balai Bahasa Sulawesi Utara.

Ratna, Nyoman Kutha. 2013. Teori, Metode, dan Teknik Penelitian Sastra: dari Strukturalisme hingga Postmodernisme Perspektif Wacana naratif. Yogyakarta: Pustaka Pelajar.

Soetarno. 2008. Peristiwa Sastra Melayu Klasik. Surakarta: Widya Duta Grafika.

Transkrip Wawancara Ungkapan Kepercayaan Rakyat dari Informan.

Yulianto, A. (n.d.). Pantun Banjar sebagai Media Pendidikan Karakter, 102-112. 